\title{
Biochemical

\section{Phyllanthus amarus augments the serum antioxidant capacity and invigorates the blood in experimental mice}

Akporowhe S.* and Onyesom I.

Department of Medical Biochemistry, Delta State University, Abraka, Nigeria

\begin{abstract}
The presence of antioxidant molecules in plants is well documented and there is increasing demand for natural antioxidants over synthetic additives in food and pharmaceutical industries. Phyllanthus amarus is a broad spectrum medicinal plant that has received global recognition and is known to contain certain antioxidant chemicals, but knowledge on the impact of such chemicals on in vivo antioxidant defense capacity is still accumulating. This present study, therefore, investigated changes in serum total antioxidant capacity (TAC) and associated levels of oxidative assault (Malondialdehyde, MDA) in mice administered graded amounts of Phyllanthus amarus ethanolic leaf extracts. Forty (40) adult Swiss albino mice, weighing between 20-30g were randomly divided into four groups (n=10/group) for the investigation. Group 1: Control (given placebo - normal saline); Group 2: Experimental (administered $150 \mathrm{mg} / \mathrm{kg} / \mathrm{d}$ of $P$. amarus ethanolic leaf extract, respectively). Each group was so treated for 7 days and then observed for another 14days. After the 7-day treatment and 14-day observation periods, the mice were sacrificed ( $\mathrm{n}=5$ /group/each day) under chloroform anaesthesia usually after an overnight fast. Whole blood was there after collected and centrifuged to obtain serum sample for the biochemical assay of total antioxidant capacity (TAC) and malondialdehyde (MDA) using documented methods. Results show that administration of $P$. amarus for 7 days and 14 days observation thereafter, significantly $(\mathrm{p}<0.05)$ increased total antioxidant capacity (TAC) administered at $(150 \mathrm{mg} / \mathrm{kg} / \mathrm{d}: 0.29 \pm 0.0 \mathrm{mM}$ and $0.19 \pm 0.05 \mathrm{mM}, 300 \mathrm{mg} / \mathrm{kg} / \mathrm{d}: 0.30 \pm 0.04 \mathrm{mM}$ and $0.23 \pm 0.03 \mathrm{mM}, 450 \mathrm{mg} / \mathrm{kg} / \mathrm{d}$ : $0.29 \pm 0.01 \mathrm{mM}$ and $0.25 \pm 0.06 \mathrm{mM})$ with associated reductions in the levels of malondialdehyde $(150 \mathrm{mg} / \mathrm{kg} / \mathrm{d}: 26.33 \pm 3.51 \mu \mathrm{M}$ and $30.67 \pm 6.66 \mu \mathrm{M}, 300 \mathrm{mg} / \mathrm{kg} / \mathrm{d}: 23.33 \pm 2.50 \mu \mathrm{M}$ and $27.67 \pm 3.72 \mu \mathrm{M}$, and $450 \mathrm{mg} / \mathrm{kg} / \mathrm{d}: 28.67 \pm 6.66 \mu \mathrm{M}$ and $31.67 \pm 3.51 \mu \mathrm{M})$ when compared with control values $(\mathrm{TAC}=0.13 \pm 0.06 \mathrm{mM}$ and $0.09 \pm 0.02 \mathrm{mM}, \mathrm{MDA}=38.00 \pm 6.16 \mu \mathrm{M}$ and $40.00 \pm 1.53 \mu \mathrm{M})$. Data indicate that crude ethanolic leaf extract of $P$. amarus improved antioxidant defense capacity and invigorated the blood of experimental mice. This vitalizing property may be due to $P$. amarus antioxidant phytocompounds already identified. The bioavailability and antioxidant boosting capacity of these chemical ingredients are hereby demonstrated in experimental mice.
\end{abstract}

KEY WORDS: PHYLLANTHUSAMARUS, TOTAL ANTIOXIDANT CAPACITY, MALONDIALDEHYDE, BLOOD, OXIDATIVE ASSAULT

\author{
ARTICLE INFORMATION: \\ *Corresponding Author: simacoakpos@yahoo.com \\ Received $21^{\text {st }}$ December, 2016 \\ Accepted after revision $20^{\text {th }} \mathrm{Feb}, 2016$ \\ BBRC Print ISSN: 0974-6455 \\ Online ISSN: 2321-4007 \\ 11:i: Thomson Reuters ISI SCI Indexed Journal \\ NAAS Journal Score : 3.48 \\ - A Society of Science and Nature Publication, 2016. All rights \\ reserved. \\ Online Contents Available at: http//www.bbrc.in/
}




\section{INTRODUCTION}

Herbs have been investigated for their antioxidant properties (Gazzaneo et al., 2005) and medicinal plants containing active chemical constituents with high antioxidant activity play important role in prevention of various degenerative diseases (Lukmanul et al., 2008). Antioxidants can abstract lone electron from free radical molecules such as reactive oxygen species, ROS and help humans to control these harmful substances. ROS, are usually produced in the body by chemical reactions which occur during normal or pathological cellular processes (Lakenbrink et al., 2000 and Onyesom et al., 2015).

Excess formation of these ROS can overwhelm body defense and cause oxidative stress. Oxidative stress plays significant roles in processes of ageing and pathogenesis of numerous diseases like diabetes, cancer, neurodegenerative and respiratory tract disorders (Anderson et al., 2000). Halliwell (1996), opined that the sum of endogenous and food derived antioxidants represents thetotal antioxidant capacity of a system. The role of antioxidant is to detoxify reactive oxygen intermediates in the body (Delay, 1993). Therefore,improved antioxidant status can minimize oxidative stress and associated damages. This delays or decreases the risk of developing free radical induced diseases.

Protective antioxidants bestowed by many plant extracts and products make these agents promising therapeutic drugs for free radicals induced pathologies. Phyllanthus amarus (P. amarus) is a medicinal plant of the family Euphorbiacae. It has about 800 species which are found in tropical and subtropical regions of the world including Nigeria (Mazumderetal., 2006). Phyllanthus amarus is used as a chemoprotective agent (Kumar and Kulta, 2005), and it has been observed to exhibit hypoglycaemic property (Kussuya et al., 2003). Recently we have demonstrated that crude ethanolic leaf extract of $P$. amarusrestored renal dysfunction associated with $P$. berghei malarial parasite- induced oxidative stress in experimental mice (Onyesom et al., 2015). P.amarus has been reported to contain antioxidant phytocompounds, but this study, however, investigated the bioavailability and impact of these substances in graded crude ethanolic leaf extract on serum total antioxidant capacity and associated levels of oxidative stress in experimental mice.

\section{MATERIALS AND METHODS}

\section{HARVESTING AND PREPARATION OF PLANT EXTRACT}

Fresh whole plants of wild type Phyllantusamarus growing in uncultivated farmland in Abraka, Ethiope East
Local Government Area of Delta State, Nigeria were obtained in May, 2015 and authenticated (No: FHI: 109728) in the Herbarium Unit, Forest Research Institute of Nigeria, Ibadan. Crude ethanolic leaf extract of the harvested plant was prepared as earlier described (Onyesom et al., 2015).

\section{ANIMAL GROUPING AND EXTRACT ADMINISTRATION}

Forty (40) adult Swiss albino mice of mixed sexes weighing between 20-30g were assigned into four (4) groups ( $n=10 /$ group). Group 1: Control (was given placebo - normal saline), Groups 2, 3 and 4: Experimental (were administered placebo - 150, 300 and $450 \mathrm{mg} / \mathrm{kg} / \mathrm{d}$ of $P$. amarus ethanolic leaf extract, respectively). The graded doses of extract were prepared and administered as already documented (Onyesom et al., 2015).

\section{ANIMAL SACRIFICE AND COLLECTION OF SPECIMEN}

After 7 days of extract administration and another 14 days of observation, the mice were fasted overnight and sacrificed ( $n=5$ mice per each time) the next day under chloroform anaesthesia.Whole blood was collected by heart puncture and centrifuged (Cent 80D, Serico, China) to obtain serum which was used for the biochemical analyses of total antioxidant capacity, TAC and malondialdehyde, MDA levels in blood.

Serum TAC was determined by the Trolox Equivalent Antioxidant Capacity (TEAC) method described by Miller et al., (1993) and MDA level was estimated by assessing amount of Thio Barbituric Acid Reacting Substances (TBARS) (Ohkawa et al., 1979).

\section{STATISTICAL ANALYSIS}

Data were assessed by the one way analysis of variance (ANOVA) and Dunnett's post hoc test using SPSS software package version 20. Level of significant difference was established at $p<0.05$.

\section{RESULTS AND DISCUSSION}

The results obtained from the investigation into the total antioxidant capacity and malondialdehyde levels in serum of mice administered with graded crude ethanolic leaf extract of Phyllanthus amarusare presented in Table 1.

Table 1 showed the data on total antioxidant capacity, TAC as well as malondialdehyde, MDA levels in experiment mice administered graded doses of crude ethanolic leaf extract of Phylanthus amarus. 


\begin{tabular}{|c|c|c|c|c|}
\hline \multicolumn{5}{|c|}{$\begin{array}{l}\text { Table 1: Total antioxidant capacity, TAC and lev } \\
\text { MAD in serum of experimental mice administer } \\
\text { ethanolic leaf extract of Phyllanthus amarus } \\
\operatorname{TAC}(\mathrm{mM}) \operatorname{MDA}(\mu \mathrm{M})\end{array}$} \\
\hline Group & 7 Days & 21 Days & 7 Days & 21 Days \\
\hline 1. & $0.13 \pm 0.06^{\mathrm{a}}$ & $0.09 \pm 0.02^{\mathrm{a}}$ & $38.33 \pm 4.73^{\mathrm{a}}$ & $40.33 \pm 1.53^{\mathrm{a}}$ \\
\hline 2. & $0.29 \pm 0.05^{b}$ & $0.19 \pm 0.05^{b}$ & $26.33 \pm 3.51^{\mathrm{b}}$ & $30.67 \pm 6.66^{b}$ \\
\hline 3. & $0.30 \pm 0.04^{\mathrm{b}}$ & $0.23 \pm 0.03^{b}$ & $23.33 \pm 2.50^{\mathrm{b}}$ & $27.67 \pm 3.72^{\mathrm{b}}$ \\
\hline 4. & $0.29 \pm 0.01^{\mathrm{b}}$ & $0.25 \pm 0.06^{b}$ & $28.67 \pm 6.66^{\mathrm{b}}$ & $31.67 \pm 3.51^{\mathrm{b}}$ \\
\hline \multicolumn{5}{|c|}{$\begin{array}{l}\text { Values are expressed as Mean } \pm S D \text { for } n=5 \text { mice. Values that bear another } \\
\text { superscript on a column differ significantly }(p<0.05) \text {. }\end{array}$} \\
\hline \multicolumn{5}{|c|}{ Group 1 = Control (given placebo - normal saline) } \\
\hline \multicolumn{5}{|c|}{ Group $2=$ Experimental (treated with $150 \mathrm{mg} / \mathrm{kg}$ P. amarus) } \\
\hline \multicolumn{5}{|c|}{ Group $3=$ Experimental (treated with $300 \mathrm{mg} / \mathrm{kg}$ P. amarus) } \\
\hline \multicolumn{5}{|c|}{ Group $4=$ Experimental (treated with $450 \mathrm{mg} / \mathrm{kg} P$. amarus) } \\
\hline \multicolumn{5}{|c|}{$T A C=$ Total antioxidant capacity } \\
\hline \multicolumn{5}{|c|}{ MDA = Malondialdehyde } \\
\hline
\end{tabular}

The administration of varying doses (150, 300 and $450 \mathrm{mg} / \mathrm{kg} / \mathrm{d}$ ) of Phyllanthus amarus crude ethanolic leaf extract to experimental mice significantly $(p<0.05)$ increased serum total antioxidant capacity, TAC, but reduced $(p<0.05)$ levels of malondialdehyde, MDA (an oxidative stress / lipid peroxidation biomarker) after 7 days of administration and another 14 days of observation when compared with control values at the $5 \%$ probability level.

Herbs have been investigated for their antioxidant properties (Gazzaneo et al., 2005). Medicinal plants having active chemical constituents with good antioxidant property play significant role in prevention of various (degenerative) diseases (Lukmanul et al., 2008). Natural antioxidants from plant sources are potent, safe and harmless because of their low toxicity reports (Calixtoetal., 1998; Ogbonon etal., 2008; Onocha and Ali, 2010).

This study assessed total antioxidant capacity and levels of oxidative damage in serum of mice administered crude ethanolic leaf extract of Phyllanthus amarus. The estimation of malondialdehyde, MDA levels was used to ascertain the levels of oxidative damage because MDA is one of the final products of polyunsaturated fatty acids (PUFAs) peroxidation in cells. An increase in free radicals causes overproduction of MDA. Hence, malondialdehyde level is commonly used as oxidative stress biomarker.

The results (Table 1) indicate that Phyllathus amarus crude ethanolic leaf extract administered to experimental mice in apparent good health for seven days and observation for another fourteen days thereafter induced an increase in total antioxidant capacity resulting in decreased levels of malondialadehyde. These changes were found to be significant $(p<0.05)$ when compared with control values.
Therefore, oral administration of the $P$. amarus leaf extract served as a factor that improved antioxidant defense and significantly reduce oxidative stress.

The phytochemicals identified in theleaf of Phyllanthus amarus include flavonoids, tannins, saponins, alkaloids, terpenoids, gycosides and anthroquinones(Faremi et al., 2008; Onyesom et al., 2015). Flavonoids from this plant have been shown to possess several pharmacological properties such as anti-inflammatory (Joy and Kuttan, 1998; Kassuya etal., 2003; Adeneye, 2006) and antioxidant activities (Wampa et al., 2012).

Total antioxidant capacity, TAC of systems include the summation of both endogenous and food - derived antioxidants which involve some enzymes such as superoxide dismutase, catalase and glutathione peroxidase, and arrays of small macromolecules like ascorbic acid, tocopherol, carotene, reduced glutathione (Halliwell, 1996).

Antioxidants interact with free radicals including reactive oxygen species ROS - which are usually produced by the body as a result of chemical reactions during normal cellular processes (Lakenbrink et al., 2000) in order to terminate their cell damaging activities. So, increased activities of ROS can lead to oxidative stress are known to play significant role in the process of ageing and pathogenesis of numerous diseases like diabetes, cancer, neurodegenerative diseases and respiratory tract disorders (Anderson et al., 2000).Improved antioxidant status therefore, helps to minimize oxidative damage and this could delay or decrease the risk of developing many age related free - radical induced diseases.

Evidence indicates that Phyllanthus amarus crude ethanolic leaf extract contributes to the improvement of antioxidant defense which invigorated the blood and provide health benefits at low, moderate and high doses. 


\section{CONCLUSION}

On the whole, crude ethanolic leaf extract of $P$. amarus was observed to improve antioxidant defense, reduced oxidative stress and invigorated the blood in experimental mice. This ability could be due to the bioactivities of identified phytochemicals especially phenolics (flavonoids and tannins) which have been observed to display significant antioxidant activity (Ettebong et al., 2012; Sen and Batra, 2013). As a corollary, this study hereby confirms the bioavailability and bioactivity of $P$. amarus antioxidant phytochemicals. The antioxidant phytochemicals (flavonids and tannins) should be purified and further studied in order to identify the chemical compounds that possess the invigorating property.

\section{ACKNOWLEDGEMENTS}

We gratefully acknowledge the services of Affamefune Biomedical Consult, Abraka, Delta State.

\section{REFERENCES}

Adeneye A.A., Amole 0.0. and Adenye A.K. (2006). Hypoglycemic and hypocholesterolemic activities of the aqueous leaf and seed extracts of Phyllanthus amarus in mice. Fitoterapia 77:511-514.

Alvarez J.G. andStorey B.T. (2000). Lipid peroxidation and the reaction of superoxide and hydrogen peroxide in mouse spermatozoa. Biol. Reprod. 30:833- 841.

Anderson W., Hamouz K., Orsak M. and Pivec V. (2000). Potato tubers as a significant source of antioxidants on human nutrition. Rostl. Vyr.46:231-236.

Calixto J. B., Santos A.R.S., Cechinel-Filho V. and Yunes R. (1998). A review of the plants of the genus Phyllathus: their chemistry, pharmacology and therapeutic potential. Med. Rev. 18: 225-228.

Delay E.R. (1993). Antioxidant activity and phenolic compounds in 32 selected herbs. Food Chem.105: 940-949.

Ettebong E., Nwafor P. and Okokon J. (2012). In vivo antiplasmodial activities of Eluecine indica. Asian Pacific. J. Trop. Med. 5(9):673-67.

Faremi T.Y., Suru S.M., Fafunso M.A. and Obioha U.E. (2008). Hepatoprotective potentials of Phyllanthus amarus against ethanol-induced oxidative stress in rats. Food Chem. Toxicol. 46: 2658-2664.

Gazzaneo A.S., Burkill H.M., Bohn T. and Shukla Y. (2005). Useful Plants of West Tropical Africa. Kew: Royal Botanic Garden.

Halliwell T.G., Gao L. and Oomah B.D. (1996). Antioxidant activity in selected fruits, vegetables, and grain products. J. Agric. FoodChem.46:4113-4117.

Joy K.L. and Kuttan R. (1998). Inhibition by Phyllanthus amarus of hepatocarcinogenesis induced by N-nirosodiethylamine. J. Biochem. Nutr. 24: 133-139.
Kassuya C.A., Santos A.R. and Migrel O.G. (2003). Anti-inflammatory properties of extracts, fractions and ligans isolated from Phyllanthus amarus. Plant. Med. 71:72-72.

Kumar M., Zilmer M., Lind L., Linde T. and Fellström B. (2000). Oxidative stress and endothelial function in chronic renal failure. J. Am. Soc Nephrol. 12:2747-2752,

Kumar K.B. and Kuttan R. (2005). Chemopreventive activity of an extract of Phyllanthus amarus against cyclophosphamideinduced toxicity in mice. Phytomedicine. 7:494-500.

Kuti C.E., Yang M.H., Wen H.M, Chm J .C. and Lukmanul K.Y. (2004). Estimation of Natural antioxidant in fruits and vegetables. J. Food DrugAnal.10:178-182.

Lakenbrink C and Adler R. (2000). Herbal vitamins: Lead toxicity and development delay. Pediatrics160: 600-602.

Lukmanul H., Adom G.H. and Liu P. (2005). Antioxidant and free radical scavenging potential of Achillea santolina extracts. FoodChem. 104:21-29.

Makowski J., Dandiona P., Thusu K., Cook S., Snyder B., Armstrong D. and Nicotera E. (2009). Oxidative damage to DNA in diabetes mellitus. Lancet 347:4444445

Malkowski H.O., Batari R., Sandrasari D.A., Bolling B., Wijaya H. (2009). Antioxidant activity of vegetables from Indonesia. J. Cell Biochem. 102: 61-72.

Matkowski A., Hajones M., Skalicka-Wozniak K. and Slusarczy K. (2009). Antioxidant activity of polyphenols from Lycopus lucidus Turcz. Food Chem. 120(4):88-89.

Mazamder S., Khullar M., Sharma P.C. and Nath R. (2005). Different antioxidant status, total antioxidant power and free radicals in essential hypertension. J. Cell Biochem. 87: 45-48.

Miller G., De Mattia O. and Fava D. (1993). Diabetic endothelial dysfunction :effect of free radical scavenging in Type 2 diabetic patients. J Diabet Complicat. 17:30-35.

Nwankpa P., Eteng M.U., Akpanabiatu M.I., Oze G. and Nwanjo H.U. (2012). Effect of Phyllanthus amarus on serum lipid and oxidative stress status in Salmonellae typhi infested Wistar rats. J. Nat. Prod. Plant Resour.2(5):574-578.

Obidike L., Okhale S., Aboh M.I. and Salawu O.A. (2013). Isolation, fractionation and evaluation of the antiplasmodial properties of Phyllanthus niruri resident in its chloroform fraction. Asian Pac. J. Trop. Med. 6:169-175.

Ohkawa H., Ohishi N. and Yagi K. (1979). Assay for lipid products in animal tissues by Thiobarbituric acid reaction. J. Anal Biochem. 95(2):351-358.

Onocha P.A. and Ali M.S. (2010). Antileishmaniasis, phytotoxity and cytotoxity of Nigerian Euphorbiaceous plants; Phyllanthus amarus and Phyllanthus muelleriamus extracts. J. Afr. Sci. 11(2):79-83.

Onyesom I., Onumaechi I.F., Ehiwario J and Dagana R. (2015). Antiplsmodial activity of Phyllanthus amarus preserves renal function in Plasmodium berghei infected mice. Eur. J. of Med. Plants 5(1): 10-20.

Thyagarajan H. F., Blumberg B. and Chase F. (1998). ChareaPiedra's anti-HBV and antiviral properties. Ind.J. Exp. Biol.6 (43):76-78 